\title{
The Relationship of Tourism Involvement and Servant Leadership on Organizational Citizenship Behavior in Service Industries: the Mediating Effect of Organizational Commitment
}

\author{
Netania Emilisa ${ }^{1}$, Egabetha Amirah Yudhaputri ${ }^{2}{ }$ Kristina Febriani $^{3}$ \\ \{netania@trisakti.ac.id ${ }^{1}$, egabetha@trisakti.ac.id ${ }^{2}$ \} \\ Universitas Trisakti, Jakarta, Indonesia
}

\begin{abstract}
The research purpose to analyze the influence of Tourism Involvement and Servant Leadership on Organizational Citizenship Behavior mediated by Organizational Commitment in some resorts which is located in Sentul City Bogor, Indonesia. The sample used in this study was 109 respondents who are employees of some resorts in Sentul City Bogor Indonesia and collected by purposive sampling. The methodology analysis is instrumental test such as validity and reliability, also hypothesis test using SEM (Structural Equation Model) analysis. Based on this review, there was a positive influence of Tourism Involvement on Organizational Commitment, Servant Leadership on Organizational Commitment, Tourism Involvement on Organizational Citizenship Behavior, and a Servant Leadership influence on Organizational Citizenship Behavior mediated by Organizational Commitment. The analysis suggested that supervisors and team officers can provide several tourism opportunities to employees who need to carry out tourism activities to not confound with their choices. The resorts require carrying out better service leadership so that employees can accept and be motivated to handle clients better and precisely also can maintain motivation a robust engagement to employees so that employees can know the commitment to the company. The resorts are likewise pointed out to be more transparent when making innovations in the company so as not to make protests from employees so that employees can execute their duty correctly.
\end{abstract}

Keyword: Tourism Involvement; Servant Leadership; Organizational Commitment; Organizational Citizenship Behaviour

\section{Introduction}

The success of the services industry lies in the quality of service provided by the company, special attention and providing maximum service quality to be able to achieve the company's goals of bringing new customers and protecting old consumers [1]. Resort employees are at the forefront and play an important role because they are directly involved with consumers. Research has been conducted on consumer perceptions of service activities that show 
consumers are not satisfied with service activities provided by employees because they do not provide quality service and satisfy consumer demand [2]. To deal with these problems, resorts are encouraged to develop employee commitment and build organizational citizenship behavior to do extra tasks.

Organizational citizenship behavior has been considered as a company need because it has a positive impact on the sustainability of the company [3]. In carrying out their duties, employees participate in helping colleagues to minimize the occurrence of problems related to their work [4]. Other literature argues that employees who are committed to their work are productive, responsible and good employees [5]. They tend to demonstrate service-oriented attitudes and behaviors [6]. Employees who are good at their organization always respond with consumer demand, avoid consumer complaints, make good relationships with consumers, and provide quality service, good service quality makes consumers who are tourists and travelers have a high organizational commitment and the emergence of organizational citizenship behavior due to the impact of tourism involvement on work attitudes and work behavior. Tourism Involvement influences work attitudes and work behavior because tourism impacts tourists' lives as a whole or their work-life. Work requires continuous human resources to achieve organizational goals, which causes fatigue, both physically and psychologically, to employees, workers involved in tourism activities are more likely to be more satisfied with their work-life than workers who carry out fewer tourism activities [7].

Research shows that tourism can contribute to the recovery of employee conditions, positively affecting attitudes, behavior at work, and organizational commitment [8]. In the current era, servant leadership is widely applied in various organizations. Servant leadership is a leadership style that serves fellow members. Servant leadership changes the perspective of leadership and management by empowering and sharing power with members. Servant leadership has great potential to increase employee loyalty and commitment to the organization. This is due to the emphasis on employee development, sharing leadership and building a community related to organizational citizenship behavior. Employees who are more loyal will do more tasks than assigned and servant leadership has an important role in improving organizational citizenship behavior. Servant leadership also affects employee behavior in the workplace if the organization considers welfare, appreciates the role and effects of its employees, then these employees will have a sense of responsibility in their work, develop positive behavior and be involved in activities that help the organization [9].

\section{Literature Review}

Tourism Involvement has a relationship with the work of an employee. Employees who have carried out tourism activities have better psychology because they are able to reduce fatigue and tension during work, compared to those who are not involved in tourism activities [10]. Tourism Involvement related to other tourism problems such as making a decision for a trip, leadership opinions, travel information seeking behaviour, and sustainable tourism. There are several dimensions of Tourism Involvement, according to Atadil et al. [11], including the benefits felt in tourism activities and the consequences of risks that occur in tourism, the value attached to products, purchases, or consumption in all tourism activities. The importance of pleasure in tourism activities is the probability of interrelated risks if something goes wrong. According to Husain and Ali [12], Servant Leadership is a way for leaders to serve their members by providing maximum service without thinking about personal interests. Shah et al., [9] explain the various basic principles of servant leadership, 
which include service to others, empowerment and cooperation. Servant leadership is a leader who is considerate, understands, ensures trust, has meaning, thinks about future plans, is full of care, and works for the community and the development of the group for the better.

Then servant leadership will create capable and independent organizational group members. Kiker et al., [13] argues that his research has several servant leadership characteristics are listening, empathy, healing, awareness, persuasion, conceptualization, carefulness, openness, growth, and community building. Organizational Commitment is a strong belief in goals and values for the organization and the desire to do work on their own accord [14]. There are three most important components in Organizational Commitment stated by Pingping and Huang [15] , namely: having a high sense of identity which aims at the organization, values and beliefs, willingness to contribute to the organization and willingness to stay in the organization Emilisa and Lunarindah [16] argue that Organizational Citizenship Behaviour is an attitude shown by employees who do their obligations and responsibilities. Even employees also do extra things outside their duties without any company's compensation to achieve goals in the organization. Organizational Citizenship Behaviour has five dimensions as follows: Altruism, Courtesy, Sportsmanship, Civic Virtue, and Conscientiousness.

\subsection{Hypothesis Development}

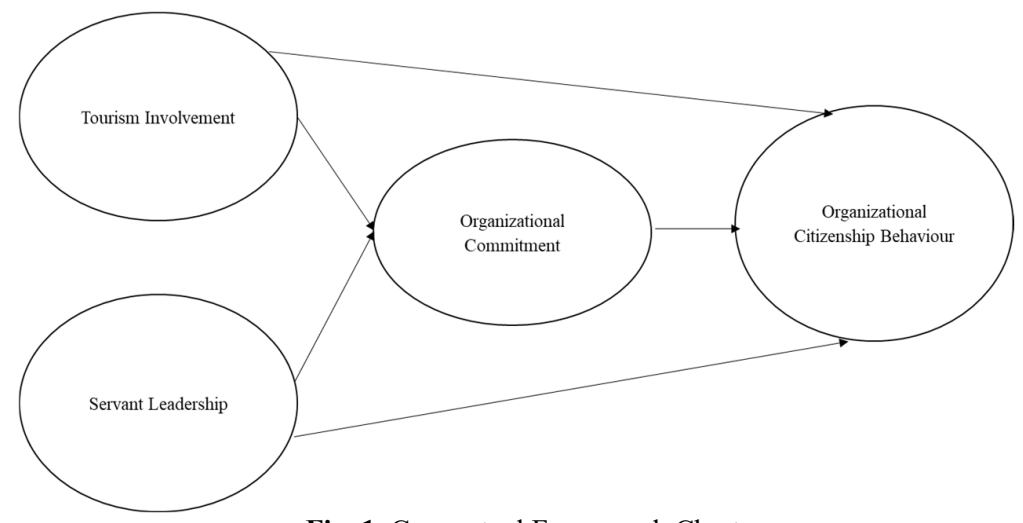

Fig. 1. Conceptual Framework Chart

Yeh [7] explained that there is a positive relationship between Tourism Involvement and Organizational Commitment that psychologically associates employees into their organization, and positively, Tourism Involvement can influence Organizational Commitment through recovery. It means that Tourism Involvement can help reduce employee fatigue in carrying out their work. If employees recover from fatigue, they will dedicate themselves to work. According to De Bloom et al. [17], tourism involvement has participated and identified as one way to recover from work activities. H1: Tourism Involvement has a positive influence on Organizational Commitment. Leaders who have good relationships with employees will affect employee loyalty to the organization.

Employees committed because employees believe that Servant Leadership can create collaboration between groups and leaders and develop their members [9]. H2: Servant Leadership has a positive influence on Organizational Commitment. Saraswati and Sulistiyo [18] said there are significant results between Organizational Commitment and Organizational 
Citizenship Behavior. It shows that high trust in leaders will support a higher level of Organizational Citizenship Behavior so that it can also increase Organizational Commitment. H3: Organizational Commitment has a positive influence on Organizational Citizenship Behavior. Employees play an essential role in the realization of organizational goals. A job requires continuous human resources to achieve its goals. Of course, this can result in fatigue.

Employees involved in tourism activities will be better able to maintain stamina from fatigue at work. By maintaining employee stamina, they will be competent and able to do more tasks voluntarily. It shows that Tourism Involvement has a positive effect on Organizational Citizenship Behavior [7,17]. H4: Tourism Involvement has a positive influence on Organizational Citizenship Behavior. Servant Leadership has the potential to improve Organizational Citizenship Behavior.

A leadership style that always pays attention to the welfare and respects its employees' role will create a sense of responsibility for employees, develop positive behavior, and engage in activities that help the organization [9]. H5: Servant Leadership has a positive influence on Organizational Citizenship. Employees who involve tourism tend to reduce their fatigue at work. With these employees' recovery, they will feel more competent, have sufficient energy, and be willing to do extra tasks voluntarily.

Tourism Involvement has a positive effect on Organizational Citizenship Behavior [7]. High organizational commitment to employees can lead to positive attitudes and behaviors. Another study [17] said that tourism has a role and is one way to recover from work. H6: Tourism Involvement has a positive influence on Organizational Citizenship Behavior mediated by the Organizational Commitment.

Servant Leadership has excellent potential to increase employee loyalty and commitment to the organization. Employees who are more loyal will do more tasks than assigned, and Servant Leadership has an essential role in improving Organizational Citizenship Behavior [9]. H7: Servant Leadership has a positive influence on Organizational Citizenship Behavior mediated by the Organizational Commitment.

\section{Research Methodology}

Sample used in this study was 109 respondents who are employees of some resorts in Sentul City Bogor Indonesia. The method used in this research is nonprobability sampling and using purposive sampling technique, which is to draw samples based on specific predetermined criteria to provide information as desired in the study [19]. The validity test results of the Tourism Involvement; there is 1 out of 16 statement items with a sig value $>0.05$ and have to be taken out from the measurement. Servant Leadership, Organizational Commitment, and Organizational Citizenship obtain significant values $<0.05$, which means that each statement item used to measure these variables is declared valid so that it can continue to the next process. All instruments in each variable have a Cronbach's Alpha value $\geq$ 0.60 , which means that all instruments used in the research are reliable.

Table 1. Characteristics of Respondents by Gender.

\begin{tabular}{ccc}
\hline Gender & Frequency & Persentace (\%) \\
\hline Male & 57 & 52.3 \\
Female & 52 & 47.7 \\
Total & 109 & 100.0 \\
\hline
\end{tabular}


Table 2. Characteristics of Respondents based on Age.

\begin{tabular}{cccc}
\hline Age & Frequency & Persentace $(\%)$ \\
\hline 18 $-\mathbf{2 5}$ years old & 68 & 62.24 \\
$\mathbf{2 6}-\mathbf{3 5}$ years old & 34 & 31.2 \\
$\mathbf{3 6}$ & $\mathbf{- 4 5}$ years old & 6 & 5.5 \\
& $\mathbf{4 5}$ years old & 1 & 0.9 \\
& Total & 109 & 100.0 \\
\hline
\end{tabular}

Table 3. Characteristics of Respondents based on Education.

\begin{tabular}{ccc}
\hline Education & Frequency & Persentace (\%) \\
\hline SMA/SMK & 43 & 39.4 \\
Diploma 3 (D3) & 35 & 32.1 \\
Sarjana 1 (S1) & 31 & 28.4 \\
Total & 109 & 100.0 \\
\hline
\end{tabular}

Table 4. Characteristics of Respondents based on Working Period.

\begin{tabular}{ccc}
\hline Working Period & Frequency & Persentace $\mathbf{( \% )}$ \\
\hline$<$ 1 year & 21 & 19.3 \\
1 - 5 years & 82 & 75.2 \\
6 - 10 years & 5 & 4.6 \\
$>$ 10 years & 1 & 0.9 \\
Total & 109 & 100.0 \\
\hline
\end{tabular}

The results of the questionnaire data analysis above show that the respondents based on the gender of the Resort employees showed that the majority of the employees there were 57 male or equal with $52.3 \%$. Respondents who have $18-25$ years as many as 68 people or described based on the percentage obtained as much as $62.24 \%$. The most recent high school or vocational school education is 43 people, or it is explained based on the percentage obtained as much as $39.4 \%$. Tenure of the employees 1 - 5 years is 82 peoples or explained based on the percentage obtained equal to $75.2 \%$.

\section{Result and Discussions}

\subsection{Results}

Hypothesis testing is done by comparing the significance value or level of significant (alpha) of 0.05 . The basis for decision making is:

1. If the value of sig. $<0.05$ then Ho is rejected, which means it has a significant positive effect. The conclusions drawn, the hypothesis decision is supported.

2. If the value of sig. $>0.05$ then Ho is accepted, which means that it does not have a significant positive effect. The conclusion drawn, the decision hypothesis is not supported. Based on the test results, the following data are obtained:

Table 5. Testing Hypotheses Result

\begin{tabular}{lccc}
\hline \multicolumn{1}{c}{ Hypotheses } & $\boldsymbol{\beta}$ & Significance & Decision \\
\hline H1: Tourism Involvement has a positive influence on & 1.124 & 0.000 & Supported \\
$\begin{array}{l}\text { Organizational Commitment } \\
\text { H2: Servant Leadership has a positive influence on }\end{array}$ & 0.340 & 0.001 & Supported \\
$\begin{array}{l}\text { Organizational Commitment } \\
\text { H3: Organizational Commitment has a positive influence }\end{array}$ & - & 0.250 & Rejected \\
\hline
\end{tabular}




\begin{tabular}{lccc}
\hline \multicolumn{1}{c}{ Hypotheses } & $\boldsymbol{\beta}$ & Significance & Decision \\
\hline on Organizational Citizenship Behavior & 0.107 & & \\
H4: Tourism Involvement has a positive influence on & 0.260 & 0.013 & Supported \\
$\begin{array}{l}\text { Organizational Citizenship Behavior } \\
\text { H5: Servant Leadership has a positive influence on }\end{array}$ & 0.080 & 0.161 & Rejected \\
$\begin{array}{l}\text { Organizational Citizenship } \\
\text { H6: Tourism Involvement has a positive influence on }\end{array}$ & - & 0.000 & Supported \\
$\begin{array}{l}\text { Organizational Citizenship Behavior mediated by the } \\
\text { Organizational Commitment }\end{array}$ & 0.051 & & \\
$\begin{array}{l}\text { H7: Servant Leadership has a positive influence on } \\
\text { Organizational Citizenship Behavior mediated by the }\end{array}$ & 0.051 & 0.000 & Supported \\
Organizational Commitment & & & \\
\hline
\end{tabular}

The analysis suggested that supervisors and team officers can provide several tourism opportunities to employees who need to carry out tourism activities to not confound with their choices. The resorts require carrying out better service leadership so that employees can accept and be motivated to handle clients better and precisely also can maintain motivation a robust engagement to employees so that employees can know the commitment to the company. The resorts are likewise pointed out to be more transparent when making innovations in the company so as not to make protests from employees so that employees can execute their duty correctly.

\subsection{Discussions}

De Bloom et al [17] stated that tourism is a way to recover from work activities and help employees from work pressure. Therefore, Tourism Involvement will have an essential impact on Organizational Commitment, with the involvement of tourism. Between employees carrying out work activities, this can help reduce employee fatigue in carrying out their work. If employees recover from their fatigue, they will dedicate themselves to doing their work more enthusiastically, and have a positive impact on increasing employees' sense of commitment to the organization. It means that the more employees involved in tourism between their work activities, the higher the Organizational Commitment that employees have towards the Resorts in Sentul City.

This study has several implication according to the data hypothesis. The first implication is, to improve Tourism Involvement at Edensor Hills Villa and Resort Sentul for the better, the company can help provide recommendations for several tourism options to employees who want to do tourism activities to make choices so that employees do not feel confused about their choices. The company can also provide various information about tourism around the Sentul tourist area. Nevertheles, to improve Servant Leadership at Edensor Hills Villa and Resort Sentul, it is necessary to implement better Servant Leadership so that employees can follow and be inspired by leaders to serve good and right guests so that later they can advance Edensor Hills Villa and Resort Sentul better and managers can help direct employees to remain professional in dealing with various work pressures and direct employees to have strong motivation to pursue company careers. Then, to improve the Organizational Commitment at Edensor Hills Villa and Resort Sentul, it can be suggested that Edensor Hills Villa and Resort Sentul can further explore the factors that support the formation of Organizational Commitment such as establishing good relationships with employees, making clear career paths for employees, appreciate the work of employees, take time to vacation as a team with employees, pay attention to job satisfaction, so as to make employees feel like part 
of the family at Edensor Hills Villa and Resort Sentul. The last one, to improve Organizational Citizenship Behavior at Edensor Hills Villa and Resort Sentul for the better, the company is advised to be more open when making changes in the organization so as not to cause complaints from employee duties, so that employees can establish a good working relationship with fellow employees so that they can help colleagues in need to complete work at Edensor Hills Villa and Resort Sentul.

\section{Conclussions}

Based on that results, it can be concluded that the Tourism Involvement has a positive influence on Organizational Commitment, the Servant Leadership has a positive influence on Organizational Commitment, and the Organizational Commitment does not have a positive effect on Organizational Citizenship Behavior, the Tourism Involvement variable has an influence positive on OCB, the Servant Leadership does not have a positive effect on OCB, the Tourism Involvement does not have a positive effect on Organizational Citizenship Behavior mediated by Organizational Commitment, the Servant Leadership has a positive influence on Organizational Citizenship Behavior mediated by Organizational Commitment.

\section{References}

[1] Irwansyah; Indra R. PENGARUH KUALITAS PELAYANAN, HARGA, DAN PROMOSI TERHADAP KEPUASAN PELANGGAN DAN MINAT MENGINAP KEMBALI (Survei pada tamu hotel $\mathrm{M}$ Borro, Baturraden). Universitas Muhammadiyah Purwokerto; 2017.

[2] Yeh, C. M. TOURISM INVOLVEMENT , WORK ENGAGEMENT AND JOB SATISFACTION AMONG FRONTLINE. Ann Tour Res. 2013;(42):214-239.

[3] Bergeron D, Ostroff C, Schroeder T., Block C. The Dual Effects of Organizational Citizenship Behavior: Relationships to Research Productivity and Career Outcomes in Academe. Hum Perform. 2014;27(2):37-41.

[4] Kim. E-J, Park S. The role of transformational leadership in citizenship behavior Organizational learning and interpersonal. Int J Manpow. 2019;40(7):347-1360.

[5] Qiu, S., \& Dooley L. Servant leadership Development and validation of a hospitality industry. 2019;40(2):193-212.

[6] Kusluvan, S., Kusluvan, Z., Ilhan, I. and Buyruk L. The human dimension: a review of human resources management issues in the tourism and hospitality industry. Cornell Hosp Q. 2010;51(2):171-214.

[7] Yeh CM. THE RELATIONSHIP BETWEEN TOURISM INVOLVEMENT, ORGANIZATIONAL COMMITMENT AND ORGANIZATIONAL CITIZENSHIP BEHAVIORS. Tour Hosp Manag. 2019;25(1):75-94.

[8] Syrek, C.J., Weigelt, O., Kühnel, J. and De Bloom J. All I want for Christmas is recovery- changes in employee affective well-being before and after vacation. Work Stress. 2017;32(4):313-33.

[9] Shah, M., Batool, N. \& HS. THE INFLUENCE OF SERVANT LEADERSHIP ON LOYALTY AND DISCRETIONARY BEHAVIOR OF EMPLOYEES: EVIDENCE FROM HEALTHCARE SECTOR. J Bus Econ. 2019;11(2):99-110.

[10] Chen, C., Huang, W., \& Petrick JF. Holiday recovery experiences, tourism satisfaction 
and life satisfaction e Is there a relationship ? Tour Manag. 2016;(54):140-147.

[11] Atadil, H.A., Sirakaya-Turk, E., Meng F and D. Exploring travelers' decision-making styles. Int J Contemp Hosp Manag. 2018;30(1):618-36.

[12] Hussain, T., \& Ali W. Effect of Servant Leadership on Followers Job Performance. Sci Tech Dev. 2012;31(4):359 - 368.

[13] Kiker, D., S., Scully, C., J., \& Kiker, M. B. Exploring the Boundaries of Servant Leadership: A Meta-Analysis of the Main and Moderating Effects of Servant Leadership on Behavioral and Affective Outcomes. J Manag Issues Summer. 2019;31(2):172-97.

[14] Flavian, C., Guinalíu, M., \& Jordan P. Antecedents and consequences of trust on a virtual team leader. Eur J Manag Bus Econ. 2019;28(1):2-24.

[15] Pingping, C., \& Huang, Y. J. A STUDY OF ASSOCIATION AMONG DISTRIBUTED LEADERSHIP , ORGANIZATIONAL COMMITMENT AND ORGANIZATIONAL CITIZENSHIP BEHAVIOR OF PRIVATE COLLEGES IN CHINA. 2019;12(2):105-114.

[16] Emilisa, N., \& Lunarindiah G. The Effect of Employee Perceived Reputation to Organizational Citizenship Behavior: A Study of Professional Event Organizer's Employees. Rev Integr Bus Econ Res. 2018;7(2):52-62.

[17] Bloom, J. De, Geurts, S. A. E., Taris, T. W., \& Sonnentag S. Work \& Stress : An International Journal of Work, Health \& Organisations Effects of vacation from work on health and well-being: Lots of fun, quickly gone. An Int J Work Heal Organ. 2010;24(2):196-216.

[18] Saraswati, V. A., \& Sulistiyo SD. The Influence of Job Satisfaction and Organizational Commitment to the Organizational Citizenship Behavior in PT. Haier Sales Indonesia Bandung Branch. J Eng Appl Sci. 2017;12(2):439-46.

[19] Sekaran U, Bougie R. Metode Penelitian untuk Bisnis: Pendekatan PengembanganKeahlian. Edisi 6. Jakarta Selatan: Salemba Empta; 2017. 